\title{
THE SEVERE 1374 RHINE RIVER FLOOD EVENT IN PRESENT TIMES
}

\author{
ANOUK BOMERS ${ }^{(1)}$, RALPH MJ SCHIELEN ${ }^{(1,2)} \&$ SUZANNE JMH HULSCHER ${ }^{(1)}$ \\ (1) University of Twente, Dienstweg 1, Enschede, The Netherlands \\ a.bomers@utwente.nl \\ (2) Dutch Ministry of Infrastructure and Water Management-Rijkswaterstaat, Arnhem, The Netherlands
}

\begin{abstract}
The severe 1374 Rhine river flood represents the largest flood in the past 1,000 years and exceeds the maximum discharge measured at Cologne, Germany, so far. The Dutch water policy is designed such that it should be able to withstand design discharges with a maximum return period of 100,000 years. The question arises whether the current flood protection measures along the Dutch Rhine river branches are sufficient to cope with an extreme event that is as severe as the 1374 flood event. In this study, a 1D-2D coupled model is set up to accurately simulate flood wave propagation with low computational cost. This model is used to simulate the consequences of the 1374 flood event in present times. The study shows that the maximum discharge along the Lower Rhine decreases significantly in downstream direction as a result of dike breaches and overflow. Therefore, the amount of water that reaches the Netherlands through the main channel is restricted to a maximum value. However, overland flow patterns influence the discharge partitioning of the Rhine river branches. Furthermore, the overland flow patterns change the most vulnerable areas in terms of flood risk.
\end{abstract}

Keywords: historic flood; coupled model; dike breaches; discharge partitioning; overland flow patterns

\section{INTRODUCTION}

Floods are a major source of disasters worldwide. Large floods such as the Rhine floods (Germany and the Netherlands) in 1993 and 1995, the Elbe flood (Germany) in 2002 and the Eden flood (UK) in 2015, show the need for accurate design of flood defences with an appropriate safety level. Design discharges associated with a specific return period are used to design flood defences to protect the hinterland from inundations. These design discharges are commonly determined with the use of a flood frequency analysis (FFA). In an FFA, annual maximum measured discharges are used to identify the parameters of a probability distribution. From this fitted distribution, discharges corresponding to any return period can be computed.

However, the data sets of measured discharges are generally in the order of 100 years, because only since then measurements have been performed. Extrapolation to design discharges with a return period of $>1,000$ years results in large uncertainty intervals. Extending the data set of measured discharges by reconstruction of historic flood events can reduce these uncertainty intervals (Bomers et al., 2019a). Therefore, many studies tried to attempt to reconstruct historic flood events. O'Connell et al. (2012) created paleohydrologic so called bound data that could be included in an FFA with the use of Bayesian statistics. Bound data represent stages and discharges that have not been exceeded since the geomorphic surface has stabilized. Therefore, these bounds are not actual floods, but represent limits on flood stage over a measured time interval. Other studies that used Bayesian statistics to include historical information in an FFA are: Parkes and Demeritt (2016) and Reis and Stedinger (2005). Toonen et al. (2015) reconstructed Lower Rhine historical flood magnitudes of the last 450 years with the use of grain-size measurements of flood deposits. Linear regression plots between various grain-size descriptors and measured discharges were used to determine the maximum discharges of historic flood events.

None of the previous studies has normalized the historic flood events into present time discharge stages with the use of a hydraulic model. However, many interventions have been applied in most of the river systems worldwide in the last century. These interventions may have a significant effect on inundation patterns as well as on the flood extent. Therefore, the historic flood events must be normalized to study the consequences of such a flood in present times. In this paper, the Rhine delta is used as a case study. In 1374, the largest discharge of the last 1,000 years has occurred. High water marks near the city of Cologne, Germany, give insight in the maximum discharge of this historic flood. A hydraulic model is required to identify the maximum discharge at the German-Dutch border, Lobith, under current geometric conditions such that this value can be included in an FFA. Furthermore, the model results provide knowledge in the inundation patterns and flood extent of the extreme 1374 event if this event would occur in present times.

The outline of the paper is as follows. Firstly, the study area and the 1374 flood event are described in Section 2 and 3 respectively. Then, the methodology is elaborated in Section 4 . The paper ends with the results and conclusions in Sections 5 and 6 respectively. 


\section{STUDY AREA}

The 1374 flood event of the Rhine river is used as a case study. The Rhine river originates in the Alps in Switzerland. It flows through Germany where from Andernach the flood-prone area widens in downstream direction until it becomes a river delta in the Netherlands (Hooijer et al., 2004). The study area stretches from Andernach, Germany, to the Dutch cities of Zutphen, Rhenen and Druten (Fig. 1). The German part of the river is referred to as the Lower Rhine. Three major tributaries, the Sieg, Ruhr and Lippe rivers, are present along the Lower Rhine. Their hydrographs influence the maximum discharge of the Lower Rhine. In the studied area, floods mainly occur during the winter months as a result of heavy precipitation events in combination with frozen and/or saturated soil. In the annual maximum discharge series of the Lower Rhine of the last 276 years, $85 \%$ of the annual maxima took place in November until March (Apel et al., 2009).

The Lower Rhine enters the Netherlands at Lobith (Fig. 1). The average annual discharge of the Rhine river at Lobith is 2,200 m3/s, and the maximum discharge measured so far equals $12,600 \mathrm{~m}^{3} / \mathrm{s}$ in 1926 (Te Linde, 2011). In the Netherlands, the Rhine river bifurcates into the Waal river and Pannerdensch Canal. After that, the Pannerdensch Canal bifurcates into the Nederrijn and IJssel rivers. The Dutch water policy assumes a fixed discharge partitioning at extreme discharges at the various Rhine branches. It is assumed that of the total discharge that enters the Netherlands at Lobith, approximately $65 \%$ discharges into the Waal river, $19 \%$ into the Nederrijn river and only $16 \%$ into the IJssel river (Spruyt and Asselman, 2017). The flood protection measures along these river branches are based on this discharge partitioning as a function of the design discharge at Lobith. For this reason, we are concerned with whether the extreme 1374 flood event will result in a larger maximum discharge at Lobith than the flood defences are designed for. In addition, we study if the defined discharge partitioning also holds under such high discharge stages. Furthermore, the reconstructed 1374 flood event in present times can be used to extend the data set of measured discharges to decrease the uncertainty of the flood frequency relation at Lobith.

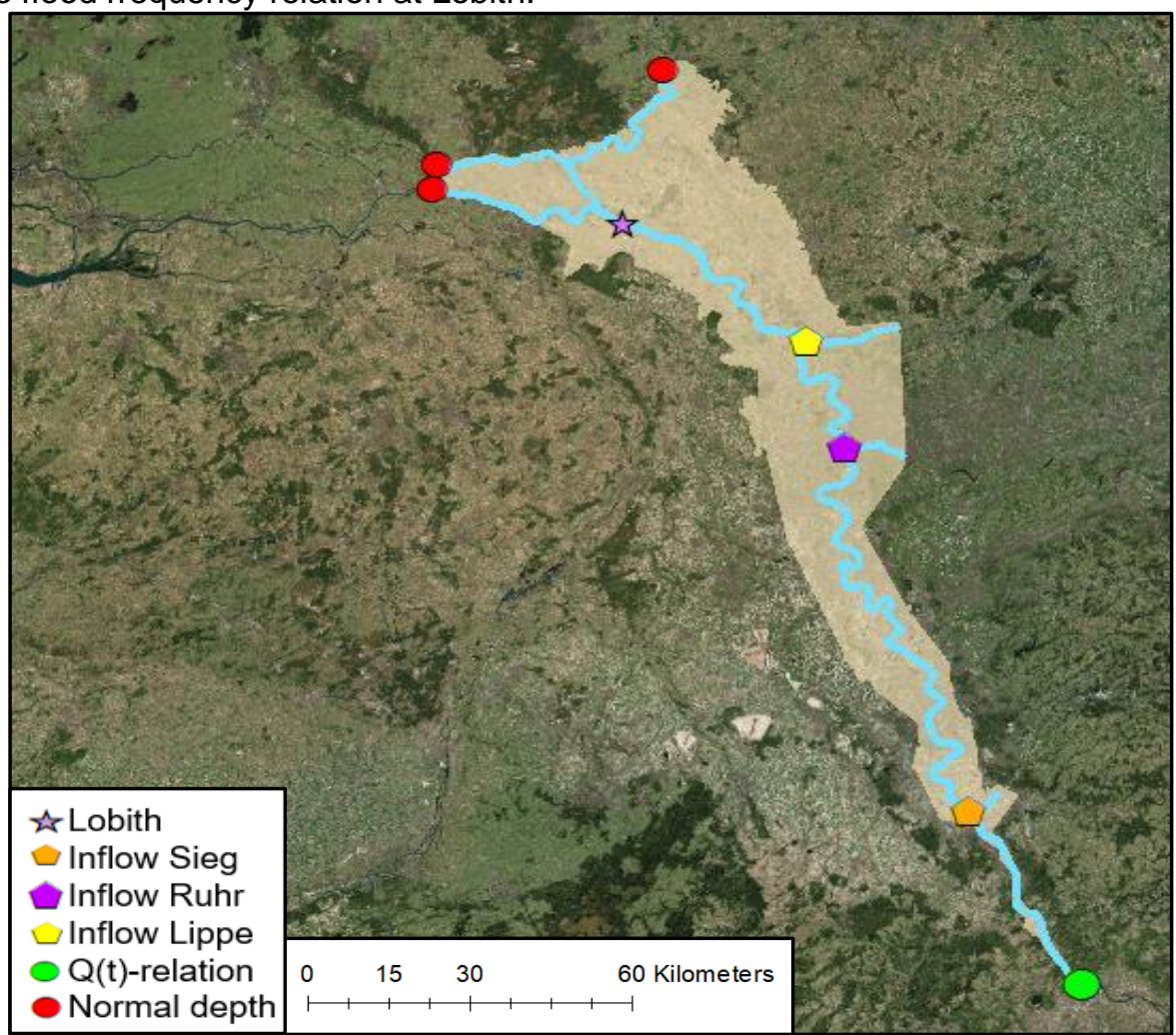

Figure 1. Overview of the study area. The upstream boundary is located at Andernach, Germany.

\section{THE 1374 FLOOD EVENT}

The year 1374 is known as the wettest winter of the last millennium (Krahe, 1997). As a result of the high rainfall intensities, three large flood events took place in the beginning of 1374 . These floods produced high water levels around January $6^{\text {th }}$, January $25^{\text {th }}$ and around the $9^{\text {th }}$ to $11^{\text {th }}$ of February (Herget and Meurs, 2010). Because of the warm temperatures, the floods all represent normal flow conditions with no occurrence of icejams. The water levels stayed extremely high until April. The flood around the $9^{\text {th }}$ to $11^{\text {th }}$ of February resulted in the highest water levels and represents the largest flood by volume ever observed at Cologne (Krahe, 1997).

Because of the exceptional high water levels during the event, a lot is written down in historic sources (e.g. news articles, diaries, paintings). This includes, amongst others, information about the maximum water level 
during the flood event. The historic sources state that it was possible to cross the city wall of Cologne by boat (Herget and Meurs, 2010). Based on these kind of sources, Herget and Meurs (2010) were able to predict mean flow velocities with the use of the empirical Manning's equation. With this predicted flow velocity, they were able to estimate the maximum discharge of the 1374 flood event based on a reconstructed river channel and floodplain bathymetry. However, since both the maximum water level as well as the reconstructed channel bathymetry were uncertain, also the predicted maximum discharge was uncertain. Herget and Meurs (2010) found an expected maximum discharge of $23,000 \mathrm{~m}^{3} / \mathrm{s}$, with a $95 \%$ confidence interval of between 18,800 $29,000 \mathrm{~m}^{3} / \mathrm{s}$. This discharge range is used as upstream boundary condition of the hydraulic model. This model is explained in more detail in the next section.

\section{METHODOLOGY}

\subsection{Model set-up}

To study the consequences of the 1374 flood event, a one dimensional-two dimensional (1D-2D) coupled hydraulic model is developed (Bomers et al., 2019b). HEC-RAS (v. 5.0.3), developed by the Hydrologic Engineering Centre (HEC) of the US Army Corps of Engineers, is used. The main channels and their floodplains are discretized by 1D profiles. These 1D profiles are coupled with the embanked areas (located outside the protection of the dike system) which are discretized by a 2D grid. A 2D grid is used in the embanked areas to correctly simulate overland flow patterns. This is because 1D profiles are insufficient to correctly predict hydrodynamic conditions in case of rapid changes in flow velocity and direction. The 2D grid cells are aligned with line segments with higher grounds (e.g. elevated highways) to sufficiently capture the characteristics of the DEM. The 2D grid consists of rectangular grid cells. Only along the boundaries of the model domain and the line segments, flexible grid shapes are used (e.g. triangular, rectangular, pentagonal cells). With the use of these flexible grid cells, the 2D grid is capable of following the boundaries of the model domain and higher grounds (Fig. 2). The 1D profiles and 2D grid cells are coupled by a structure corresponding with the dimensions of the flood defence that protects the embanked areas from being flooded. If the water level inside the 1D profile exceeds the crest level of the flood defence, water starts to flow into the 2D grid. This corresponds with inundation of the embanked areas.

The Diffusive Wave equations are used to solve the system. A discharge wave at Andernach is used as upstream boundary condition. The hydrographs of the three tributaries along the Lower Rhine are included in the model as lateral inflows (Fig. 1). Normal depths are implemented as downstream boundary conditions which can be computed with the use of the Manning's equation.

To model dike breach development, the build-in time growth template in HEC-RAS is used. In this template, an S-function is assumed such that the dike breach width increases slowly at first and then accelerates as time advances. When the breach is almost fully developed, the growth in breach width slows down again (Gee, 2010). The input parameters influencing the development of a dike breach (dike breach threshold, formation time and final breach width) are uncertain. Since they may affect overland flow patterns, they are included in the Monte Carlo analysis as random variables (see Section 4.2).

To ensure that the model predicts measured water levels accurately, model calibration was performed by adapting the roughness of the main channel (Bomers et al., 2019c). The model was calibrated with the 1995 flood wave data. After calibration, the 1993 discharge wave was routed for validation. Validation was performed at 14 measurement stations. It was found that the model predicts maximum water levels close to field measurements. An average deviation of $7 \mathrm{~cm}$ was found. Additionally, the model is capable of predicting maximum discharges with high accuracy. The maximum deviation was found along the Waal river where the simulated maximum discharge differs $3.7 \%$ from the measured data. These validation results give confidence in the accuracy of the model. 


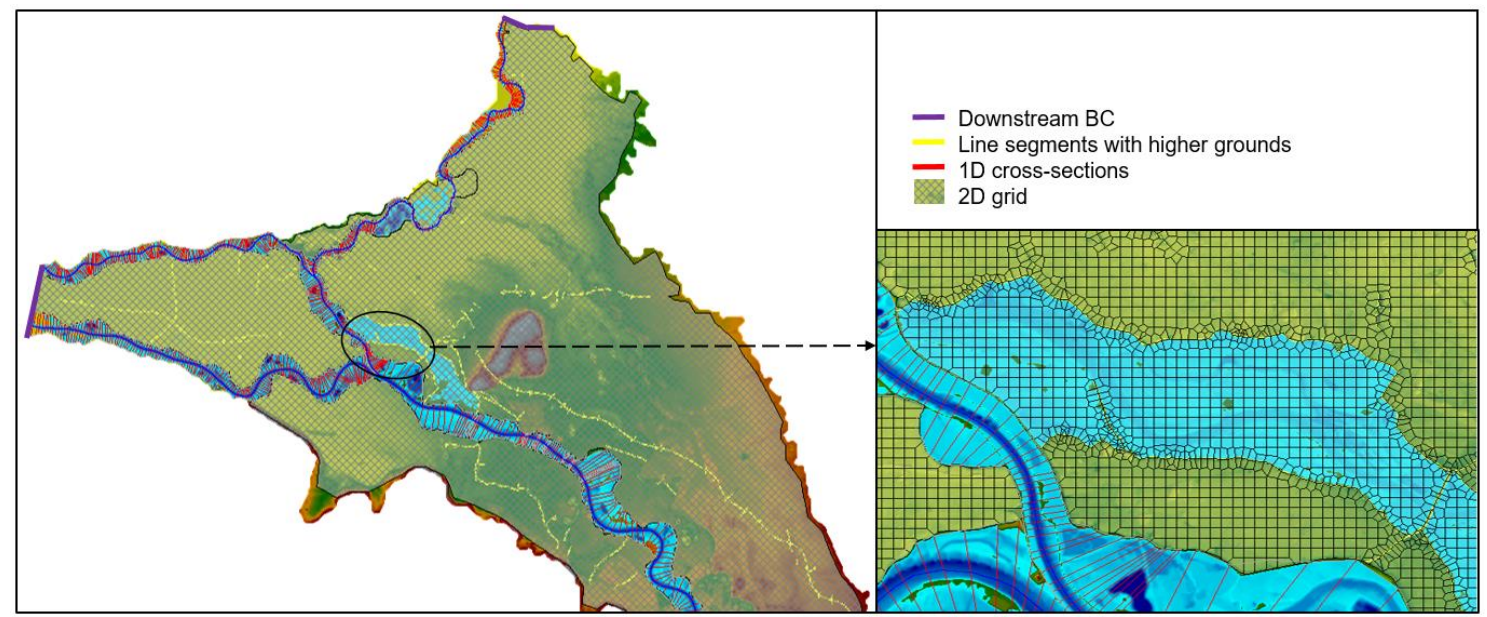

Figure 2. The model set-up (left figure) with a close-up of the 2D grid which is aligned with higher grounds (right figure).

\subsection{Monte Carlo analysis}

Most probably dike breaches occur if an extreme event like the 1374 event would take place nowadays. However, where dike breaches will occur is highly uncertain. Therefore, a Monte Carlo analysis is used to include potential dike breach locations as random input parameter. For simplicity reasons, it is assumed that dike breaches can only occur along the river branches that are located downstream of the confluence with the Lippe river (Fig. 1). Upstream of this location, only overflow is possible to occur as a result of high water levels. This is because a dike breach in these areas do not affect discharge partitioning of the Dutch Rhine river branches. In total, 33 potential dike breach locations are implemented in the model (Fig. 3). Only the locations where a dike breach results in significant overland flow as well as the locations where the overland flow may flow back into the river system again are considered. This results in the most extreme scenarios since these dike breach locations have the potential to alter the discharge partitioning along the Dutch Rhine river branches.

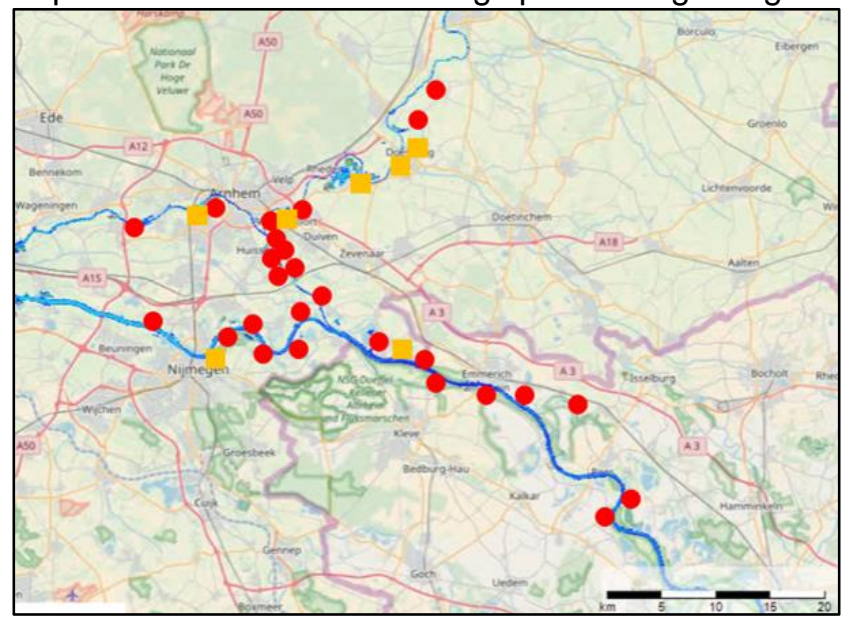

Figure 3. Potential dike breach locations included in the MCA. The red circles indicate the locations where water can leave the river system. The orange rectangles represent the locations where water may flow back into the river system again after flowing over land.

Not only the development of the dike breaches are uncertain. Also, the shape and maximum value of the 1374 discharge wave at Andernach and the discharge waves of the three main tributaries are uncertain. Therefore, the following parameters are considered to be random, following the method of Apel et al. (2009) and Vorogushyn et al. (2010):

- Upstream discharge wave in terms of discharge shape and peak value

- Discharge wave of the main tributaries in terms of discharge shape and peak value

- Dike breach threshold indicating at which water level the dike starts to breach

- Dike breach formation time

- Final breach width

An overview of the Monte Carlo analysis is given in Fig. 4. For each Monte Carlo run, an upstream discharge wave and corresponding inflows of the three main tributaries are sampled. The 1D-2D coupled model computes the water levels along the various river branches as a result of the boundary conditions and lateral 
inflows. At every time step, the model evaluates whether the simulated water level exceeds the sampled dike breach threshold at every potential dike breach location. If the critical water level is exceeded, the flood defence starts to breach based on the sampled dike breach formation time and final breach width. A description of the five random input parameters is given in the next sections.

\section{Input discharge waves}

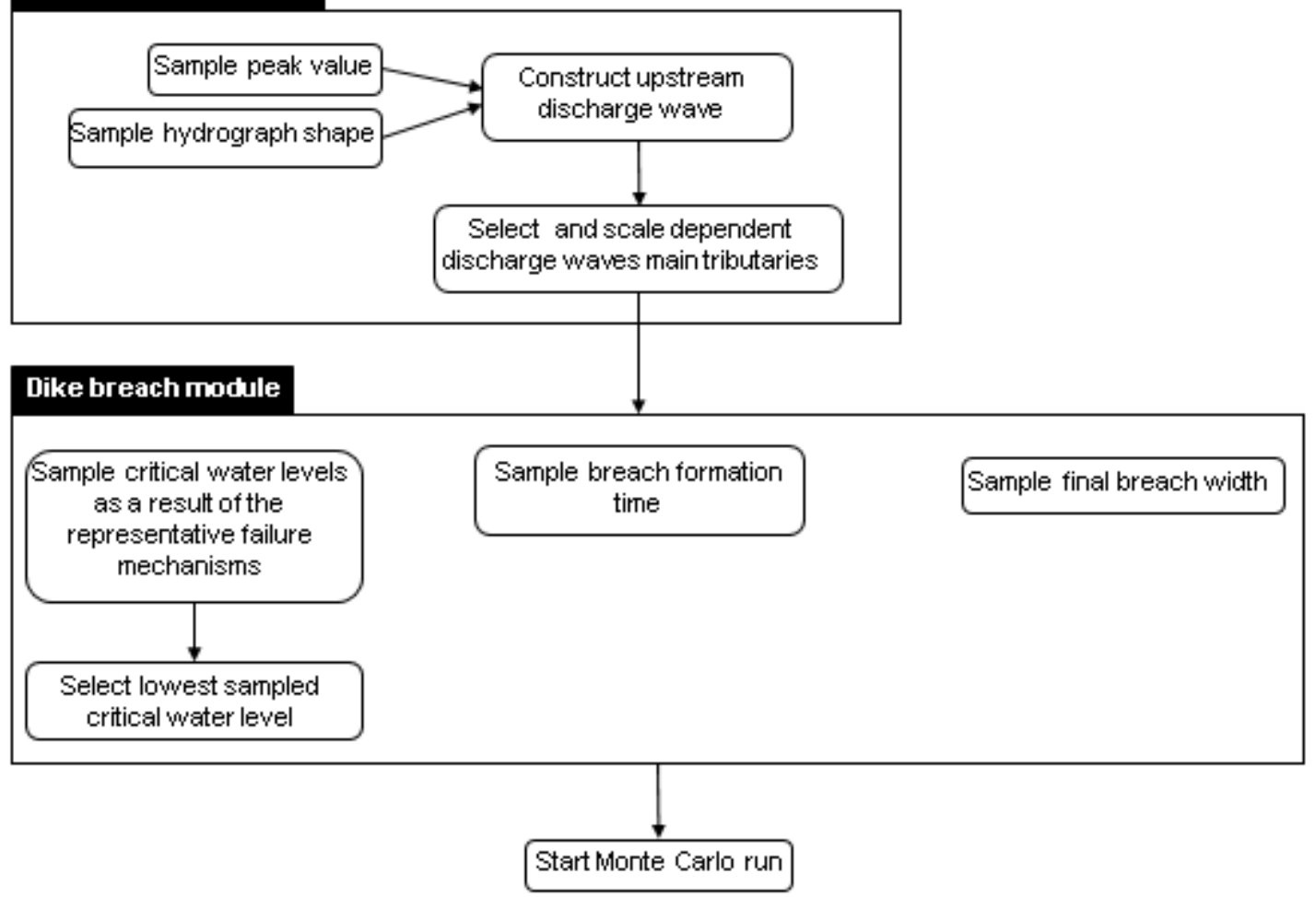

Figure 4. Overview of the Monte Carlo sampling method.

\subsubsection{Upstream discharge waves and lateral inflows}

Sampling the upstream discharge wave includes two steps. Firstly, a peak value is randomly sampled. Secondly, a discharge shape is sampled and scaled such that the peak value corresponds with the peak value sampled. The 1374 maximum discharge range is used, corresponding with a range of between $18,800 \mathrm{~m}^{3} / \mathrm{s}-$ $29,000 \mathrm{~m}^{3} / \mathrm{s}$ at Cologne (Herget and Meurs, 2010). This range and the expected value of the flood event, equal to $23,000 \mathrm{~m}^{3} / \mathrm{s}$, is used to set up the truncated normal distribution. The sampled peak value at Cologne is used to compute the maximum discharge at Andernach. For the sampling of the shape, we use a data set of 120 potential discharge shapes which can occur under current climate conditions at Andernach (Hegnauer et al., 2014). This data set includes a wide variety of potential shapes (e.g. a single sharp peak, a single broad peak or two peaks: Fig. 5). For each Monte Carlo run, a discharge shape is sampled. Corresponding discharge waves of the main tributaries are selected since historic flood events have shown that there is a strong correlation between the discharges of the main tributaries and the discharge along the Lower Rhine (Apel et al., 2009). The discharge waves of the main tributaries are scaled with the same factor as the discharge wave at Andernach such that the maximum discharge correspond with the peak value sampled. 


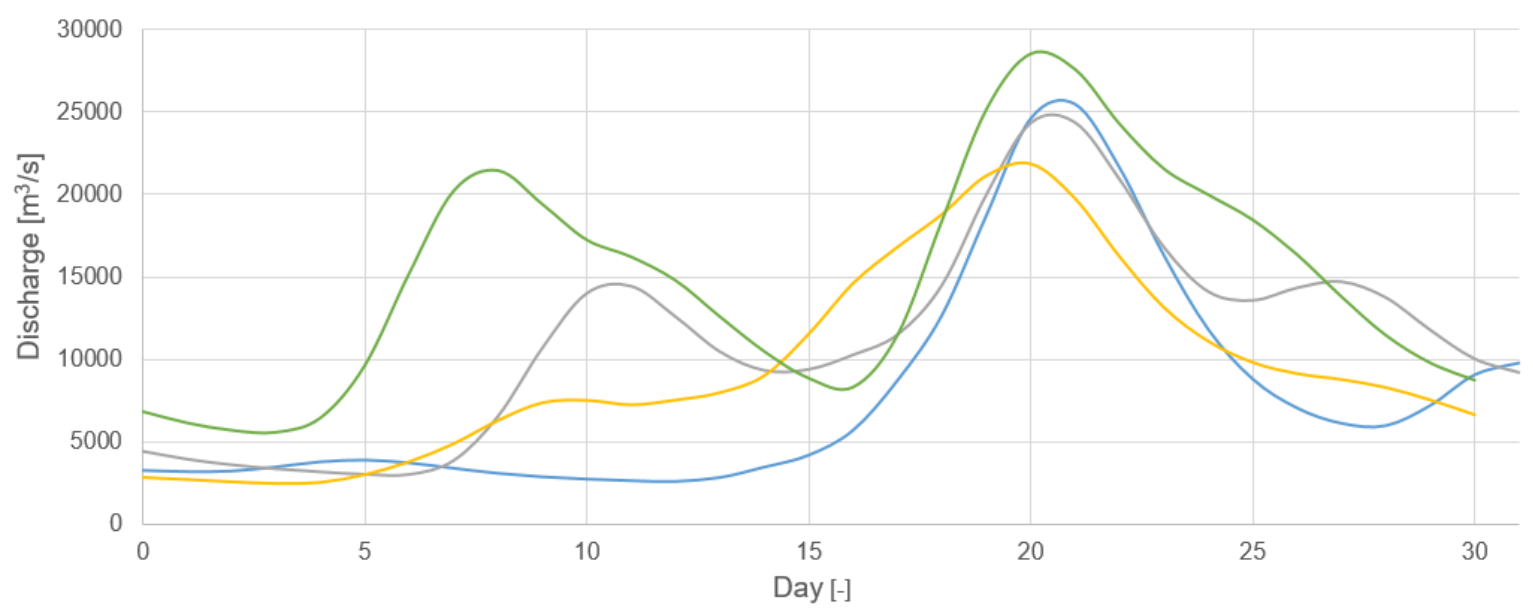

Figure 5. Potential discharge hydrographs. Both the peak value as well as the shape of the discharge waves are sampled during the MCA.

\subsubsection{Dike breach threshold}

A flood defence starts to breach when the simulated water level exceeds the sampled critical water level which represents the dike breach threshold. For the Dutch dikes, dike failure caused by failure mechanisms macro-stability, piping and wave overtopping are included in the analysis (De Bruijn et al., 2014; Diermanse et al., 2014). The truncated normal distributions of the critical water levels of these three failure mechanisms are based on 1D fragility curves provided by the Dutch Ministry of Infrastructure and Water Management. Such a curve expresses the reliability of a flood defence as a function of a defined dominant stress (Hall et al., 2003). The fragility curves can be translated into truncated normal distributions representing the failure probabilities as a function of the water levels. To exclude flood scenarios with an extremely low probability of occurrence, the critical water levels are bounded by their $95 \%$ confidence interval.

For the German dikes, no 1D fragility curves were available. Therefore, it is assumed that the Dutch curves of the part between Lobith and the first bifurcation point where the Lower Rhine bifurcates into the Waal river and Pannerdensch Canal (Fig. 1) are representative for the flood defences in Germany as well. Only the failure mechanism wave overtopping is included for the German flood defences (Apel et al., 2009).

Each potential dike breach location can fail as a result of high water levels at the outer side and inner side of the flood defence. Since no information is available about the strength of the flood defences in case of hydraulic load on the inner side, it is assumed that the flood defences are symmetric in shape. Hence, the fragility curves of the outer side of the flood defences can be applied for the inner sides as well.

\subsubsection{Dike breach formation}

The dike breach formation depends on the sampled final breach width and breach formation time. The breach formation time represents the time until the breach has developed until its final width. The flood defence has then breached to the level of the surrounding terrain. The truncated normal distributions of the dike breach formation time is based on historical data. Data of 28 dike breaches resulted in an average formation time of 13 hours and a standard deviation of 17 hours (Verheij and Van der Knaap, 2003). The distribution is bounded by a minimum formation time of $6 \mathrm{~min}$ and a maximum time of 50 hours, corresponding with the range present in the data set.

The truncated normal distribution of the final breach width is based on the data of Apel et al. (2008) and Verheij and Van der Knaap (2003). Data of 46 dike breaches resulted in an average width of $75 \mathrm{~m}$ with a standard deviation of $55.5 \mathrm{~m}$. The distribution is bounded by a minimum breach width of $3 \mathrm{~m}$ and a maximum width of $200 \mathrm{~m}$, representing the range of the data set.

\subsubsection{Sampling method}

Latin Hypercube sampling (LHS) is used as sampling strategy. This is because an LHS requires less model runs compared to other comparable sampling methods (e.g. fully random, full factorial design, central composite design) if many uncertain input parameters are included in the analysis (Saltelli et al., 2008). The distributions of the uncertain input parameters are divided into eight levels, each having a probability of occurrence of $12.5 \%$. For each run, a level is randomly sampled constraining that if a level is already sampled it cannot be sampled again. This results in a set of eight simulations in which all eight levels of the input parameters are present. Only 
for the discharge shape at Andernach, a random sampling technique is used since each potential discharge shape has an equal probability of occurrence.

\section{RESULTS}

In total, 272 runs were performed in the Monte Carlo analysis. The results of these runs are provided in the next sections. Firstly, the maximum discharge at Lobith as a result of the 1374 flood event in present times is given. Thereafter, the inundation patterns and discharge partitioning along the Dutch Rhine river branches are discussed.

\subsection{Maximum discharge}

The millennium flood of 1374 with a maximum discharge of between 18,800-29,000 $\mathrm{m}^{3} / \mathrm{s}$ at Cologne decreased significantly in downstream direction as a result of overflow and dike breaches. The maximum discharge that entered the Netherlands at Lobith is on average $15,789 \mathrm{~m}^{3} / \mathrm{s}$ with a $95 \%$ confidence interval of between $13,825-17,753 \mathrm{~m}^{3} / \mathrm{s}$. The upper bound of the $95 \%$ confidence interval is still lower than the maximum discharge that is taken into account in the national flood safety programs, which equals $18,000 \mathrm{~m} / \mathrm{s}$. Therefore, we might expect that no severe flooding would occur in the Netherlands if such an event would happen nowadays. However, the model results show a different picture. Many dike breaches, specifically along the Pannerdensch Canal, occurred.

\subsection{Inundation patterns}

In general, four significant overland flow patterns can be identified that were present during almost each scenario present in the Monte Carlo analysis (Fig. 6). These flow patterns are explained in more detail:

1. In the most upstream part of the Waal river, water leaves the river system as a result of the high discharges resulting in overflow and dike breaches. This water flows towards Germany because of the lower natural terrain level in this area. Consequently, the discharge decreases in downstream direction of the Waal river. Hence, also the potential flood risk decreases in these areas.

2. The dike located on the right bank of the Pannerdensch Canal is vulnerable for piping. The dike fails at relatively low water levels compared to surrounding dike sections. Hence, the water starts to flow through the embanked areas towards the Lower Rhine.

3. Also in the downstream part of the Pannerdensch Canal, dike breaches on the east bank occur frequently. As a result, water starts to flow parallel to the IJssel river. A part of this water may re-flow into the IJssel river at a more downstream location. As a result of the two dike breaches along the Pannerdensch Canal (resulting in flow patterns Nr. 2 and 3, Fig. 6), the discharge along the canal decreases significantly in downstream direction. Consequently, the discharges that flow towards the Nederrijn and IJssel rivers are much lower than for the situation that no dike breaches would occur. Hence, we find no extreme inundations and almost no dike breaches along the Nederrijn river and upstream part of the IJssel river.

4. The most dramatic flow pattern can be found through the Old IJssel Valley which has a relatively low natural terrain level compared to surrounding grounds. Therefore, water is capable of flowing from the IJssel river towards the Lower Rhine and vice versa. However, the flow from the Lower Rhine towards the IJssel river is more problematic due to the little discharge capacity of the IJssel river. Hence, the overland flow coming from the Lower Rhine results in a much larger inundated area compared to the consequences of dike breaches along the IJssel river. 


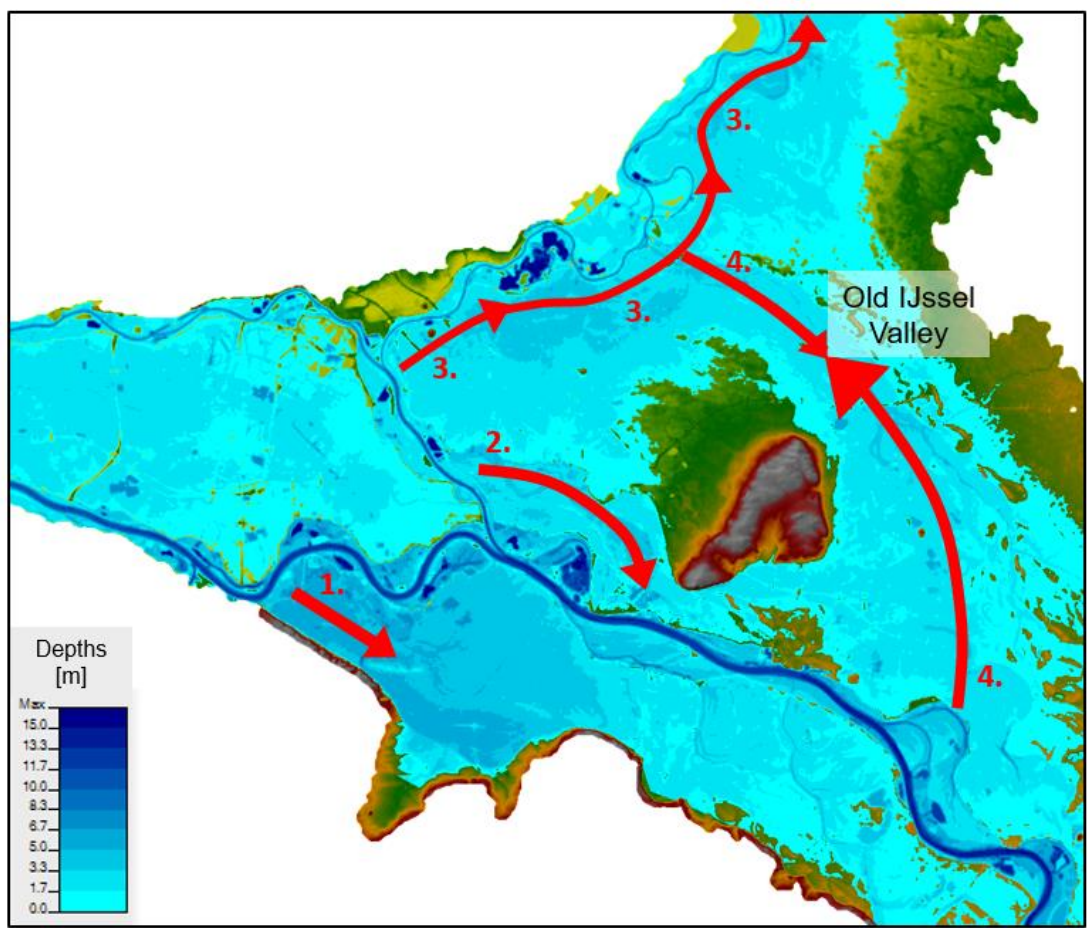

Figure 6. Most sever overland flow patterns in the Monte Carly analysis as a result of the 1374 flood event in present times.

\subsection{Discharge Partitioning}

In the Netherlands, a fixed discharge partitioning of the Dutch Rhine river branches is assumed as a function of the discharge at Lobith (Fig. 7). Considering the consequences of the 1374 flood event in present times, we find that this partitioning is more or less met for the Waal river and Pannerdensch Canal. However, significantly less water flows towards the Nederrijn and IJssel rivers as a result of the dike breaches that occur along the Pannerdensch Canal. For this reason, the summation of the discharge percentages along the Nederrijn (14\%, Fig. 7) and IJssel river (9\%, Fig. 7) is much lower than the discharge percentage that flows towards the Pannderdensch Canal (38\%, Fig. 7).

Although the discharge in the Nederrijn river and upstream part of the IJssel river are lower than defined in flood safety programs, the discharge in the downstream part of the IJssel river is much larger. On average, only $79 \%$ of the discharge at Andernach reaches Lobith. The remaining $21 \%$ flows into the embanked areas due to overflow and dike breaches along the Lower Rhine. A large amount of this water flows through the Old IJssel Valley towards the IJssel river, and a part of this water flows into the IJssel river (Overland flow pattern Nr. 4, Fig. 6). This increases the discharge of the IJssel river significantly. While the IJssel river only receives $16 \%$ of the discharge at Lobith according to the national flood safety program, this becomes $25 \%$ in the downstream part of the IJssel river (Fig. 7). The flood defences along the IJssel river are not designed to cope with such extreme discharge stages. The discharge capacity of the IJssel river is relatively low compared to the other Rhine river branches. Therefore, we expect many dike breaches to occur in the downstream part of the IJssel river. 
Discharge partitioning according to the national flood safety program

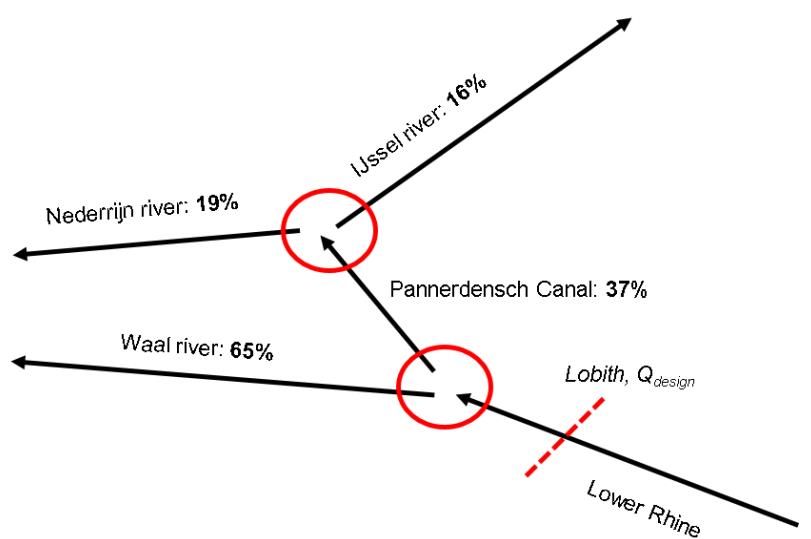

Discharge partitioning as a result of the 1374 flood event in present times

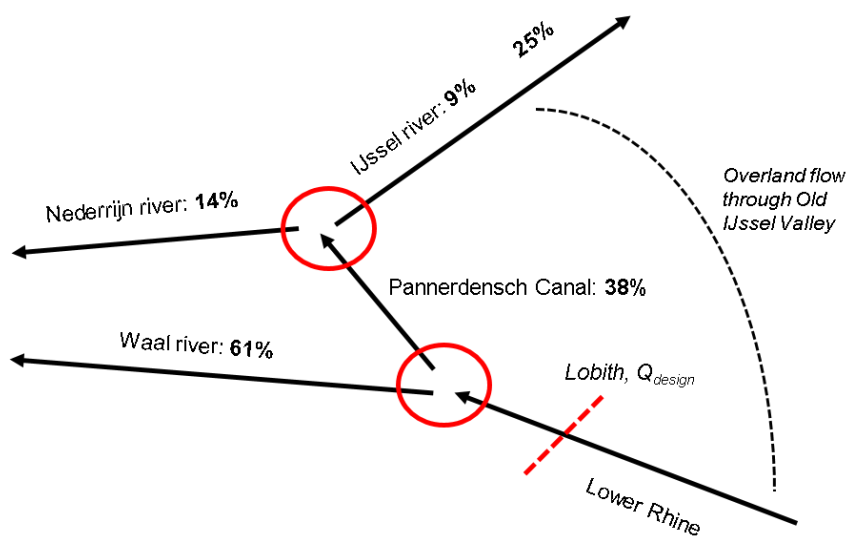

Figure 7. Discharge partitioning along the Dutch Rhine river branches according to the national flood safety program (left figure) and as a result of the 1374 flood event in present times (right figure).

\section{CONCLUSIONS}

In this study, the overland flow and inundation patterns as a result of the 1374 flood event of the Rhine river in present times was analysed. It was found that the maximum discharge that enters the Netherlands at Lobith is still lower than the maximum discharge that is taken into account in the national flood safety programs. However, as a result of dike breaches and overflow along the Lower Rhine, a great amount of water flows through the Old IJssel Valley. This overland flow pattern increases the discharge along the IJssel river. We found that the prescribed discharge partitioning which neglects the effects of overflow and dike breaches along the Lower Rhine, significantly changes as a result of both overflow and dike breaches under extreme flood conditions. Therefore, we conclude that it is of high importance that these effects are considered in future flood safety programs. In addition, we conclude that the current flood defences are not capable to cope with a flood event which is as tremendous as the 1374 flood event.

\section{ACKNOWLEDGEMENTS}

This research is supported by the Netherlands Organisation for Scientific Research (NWO, project 14506) which is partly funded by the Ministry of Economic Affairs and Climate Policy. Furthermore, the research is supported by the Ministry of Infrastructure and Water Management and Deltares. This research has benefited from cooperation within the network of the Netherlands Centre for River studies.

\section{REFERENCES}

Apel, H., Merz, B., Thieken, A.H. (2008) Quantification of uncertainties in flood risk assessments. International Journal of River Basin Management, 6(2), 149-162.

Apel, H., Merz, B., Thieken, A.K. (2009) Influence of dike breaches on flood frequency estimations. Computers and Geosciences, 35(5), 907-923.

Bomers, A., Schielen, R.M.J., Hulscher, S.J.M.H (2019a) Decreasing uncertainty in flood frequency analyses by including historic flood events in an efficient bootstrap approach. Nat. Hazards Earth Syst. Sci. Discuss., doi: 10.5194/nhess-2019-83, in review.

Bomers, A., Schielen, R.M.J., Hulscher, S.J.M.H (2019b) Application of a lower-fidelity surrogate hydraulic model for historic flood reconstruction. Environmental Modelling \& Software, doi:10.1016/j.envsoft.2019.03.019.

Bomers, A., Schielen, R.M.J., Hulscher, S.J.M.H (2019c) The influence of grid shape and grid size on river modelling performance. Environmental Fluid Mechanics, doi:10.1007/s10652-019-09670-4.

De Bruijn, K.M., Diermanse, F.L., Beckers, J.V. (2014) An advanced method for flood risk analysis in river deltas, applied to societal flood fatility risk in the Netherlands. Natural Hazards and Earth System Sciences, 14, 2767-2781.

Diermanse, F.L.M., De Bruijn, K.M., Beckers., J.V.L., Kramer, N.L. (2015) Importance sampling for efficient modelling of hydraulic loads in the Rhine-Meuse Delta. Stochastic Environmental Research and Risk Assessment, 29, 637-652.

Gee, D.M. (2010) Use of Breach Process Models to estimate Hec-Ras Dam Breach Parameters. Proceedings of the $2^{\text {nd }}$ Federal Interagency Conference, Las Vegas, USA. 
Hall, J.W., Dawson, R.J., Sayers, P.B., Rosu, C., Chatterton, J.B., Deakin, R. (2003) A methodology for nationalscale flood risk assessment. Proceedings of the Institution of Civil Engineers-Water and Maritime Engineering, 156(3), 235-247.

Hegnauer, M., Beersma, J., Van den Boogaard, H., Buishand, T., Passchier, R. (2014) Generator of Rainfall and Discharge Extremes (GRADE) for the Rhine and Meuse basins. Final Report of GRADE 2.0. Technical Report, Deltares, Delft, The Netherlands.

Herget, J., Meurs, H. (2010) Reconstructing peak discharges for historic flood levels in the city of Cologne, Germany. Global and Planetary Change, 70, 108-116.

Hooijer, A., Klijn., F., Pedroli, G.B.N., van Os, A.G. (2004) Towards sustainable flood risk management in the Rhine and Meuse river basins: Synopsis of the findings of the IRMA-SPONGE. River Research and Applications, 20(3), 343-357.

Krahe, P. (1997) Hochwasser und Klimafluktuation am Rhein seit dem Mittelalter. Hochwasser-Natur im Überfluss? 57-82.

O'Connel, D.R.H., Ostenaa, D.A., Levish, D.R., Klinger, R.E. (2002) Bayesian flood frequency analysis with paleohydrologic bound data. Water Resources Research, 28, 1058-1071, doi: 10.1029/200WR000028.

Parkes, B., Demeritt, D. (2016) Defining he hundred year flood: A Bayesian approach for using historic data to reduce uncertainty in flood frequency estimates. Journal of Hydrology, 540, 1189-1208, doi:10.1016/j.jydrol.2016.07.025.

Reis, D.S., Stendinger, J.R. (2005) Bayesian MCMC flood frequency analysis with historical information. Journal of Hydrology, 313, 97-116, doi:10.1016/j.jhydrol.2005.02.028.

Saltelli, A., Ratto, M., Andres, T., Campologno, F., Cariboni, J., Gatelli, D., Saisana, M., Tarantola, S. (2008) Global Sensitivity Analysis: The Primer. John Wiley \& Sons, Ltd.

Pruyt, A., Asselman, N. (2017) Afvoerverdeling Rijntakken. Technical Report Project 11200539-0000, Deltares, Delft, The Netherlands.

Te Linde, A. (2011) Rhine at risk? Impact of climate change on low-probability floods in the Rhine basin and the effectiveness of flood management measures. PhD thesis. Vrije Universiteit Amsterdam.

Toonen, W.H.J., Winkels, T.G., Cohen, K.M., Prins, M.A., Middelkoop, H. (2015) Lower Rhine historical flood magnitudes of the last 450 years reproduced from grain-size measurements of flood deposits using End Member Modelling. Catena, 130, 69-81, doi:10.1016/j.catena.2014.12.004.

Verheij, H.J., Van der Knaap, F.C.M. (2003) Modification breach growth model in HIS-OM. Technical Report, WL - Delft Hydraulics, Delft, The Netherlands.

Vorogushyn, S., Merz, B., Lindenschmidt, K.E., Apel, H. (2010) A new methodology for flood hazard assessment considering dike breaches. Water Resources Research, 46(8), 1-17. 